\title{
Apple Pomace as an Amendment in Container Growing Media
}

\section{Calvin Chong ${ }^{1}$ \\ Ontario Ministry of Agriculture and Food Horticultural Research Institute of Ontario, Vineland Station, Ont. LOR 2EO, Canada}

Additional index words nursery crops, organic by-product, waste usage, recycling

Each year, 1.5 million $\mathrm{t}$ of apple pomace, a primary by-product of the juice and cider industry, is produced in North America. Disposal of this organic by-product is becoming increasingly more difficult and costly (Wang and Thomas, 1989). Although composted pomace was shown to be of acceptable quality for plant growth and was especially appropriate for seedlings (van de Kamp, 1986), Parks (1979) reported generally reduced yield and vigor of vegetable crops grown in field plots amended with 16 or $24 \mathrm{t}$ of pomace/ ha. This study compared the growth and nutrient status of four nursery species in container media amended with various amounts of apple pomace.

On 15 May 1989, liners of silverleaf dogwood (Cornus alba L. 'Argenteo-marginata'), euonymus, [Euonyms fortunei (Turcz.) Hand.-Mazz. 'Emerald Gaiety'], Andorra juniper (Juniperus horizontalis Moench 'Plumosa Compacta'), and Emerald cedar (Thuja occidentalis L. 'Smaragd') were transplanted to 6-liter $(21 \mathrm{~cm}$ diameter $\times 21$ $\mathrm{cm}$ deep) nursery containers filled with a control medium or media with increasing amounts (25\% to $90 \%$ ) of apple pomace (Table 1).

Plants spaced $45 \times 45 \mathrm{~cm}$ and arranged by species in separate randomized completeblock designs with five replications and five plants per plot were grown under conditions described by Chong et al. (1991). Dogwood was grown for one season (1989), and the other species were grown for two seasons after overwintering between 1989 and 1990 in a minimally heated (-5C) polyhouse.

Duplicate samples of the unmixed $(100 \%)$ pomace and each of the five media taken on 15 May were analyzed for electrical conductivity (EC) and $\mathrm{pH}[1$ soil : 2 water extracts $(\mathrm{v} / \mathrm{v})]$, mineral nutrients, and selected physical properties (Chong et al., 1991; Ontario Ministry of Agriculture and Food, 1990). EC

Received for publication 24 Feb. 1992. This research was supported in part by Mori Nurseries, Niagara-On-The-Lake, Ont. The technical assistance of Bob Hamersma, Debbie Norton, Marion Hofstede, and Mark Zolis is appreciated. The cost of publishing this paper was defrayed in part by the payment of page charges. Under postal regulations, this paper therefore must be hereby marked advertisement solely to indicate this fact. end of the growing season. ${ }^{2}$

zJuniper was harvested 1990. and $\mathrm{pH}$ were also measured on 5 June and 6 July 1989 and 15 Apr., 13 June, 17 July, and 28 Aug. 1990 from medium samples collected (7- to $12-\mathrm{cm}$ depth) from each treatment within each replicate and pooled across species.

Mid-August leaf samples (dogwood in 1989; other species in 1990) were analyzed for total $\mathrm{N}, \mathrm{P}, \mathrm{K}, \mathrm{Ca}, \mathrm{Mg}, \mathrm{Fe}, \mathrm{Mn}$, and $\mathrm{Zn}$ (Chong et al., 1991). In early October, the shoot dry weight, height and/or width of each plant, and shrinkage in the medium in each container, expressed by depth from the container rim, were measured.

Unmixed pomace had a $\mathrm{pH}$ of 7.0 and $\mathrm{EC}$ of $0.9 \mathrm{dS} \cdot \mathrm{m}^{-1}$, the latter considered safe for plant culture. Except for a slight excess of Cl- (103 mg-liter $\left.{ }^{-1}\right)$, all other analyzed nutrients were present in low or acceptable concentrations (mg.liter $\left.{ }^{-1}\right): \mathrm{NO}_{3}, 5 ; \mathrm{P}, 7 ; \mathrm{K}$, 243; $\mathrm{Ca}, 49 ; \mathrm{Mg}, 25 ; \mathrm{SO}_{4}, 25 ; \mathrm{Na}, 57 ; \mathrm{Fe}$, $0.82 ; \mathrm{Mn},<0.10 ; \mathrm{Zn},<0.10 ; \mathrm{Cu},<0.10$; $\mathrm{B},<0.10$. Among the five media, the initial $\mathrm{pH}$ (5.4), EC (0.2 dS. $\left.\mathrm{m}^{-1}\right)$, and most nutrients were lowest in the control. Compared with the unmixed pomace or the control, corresponding values for $\mathrm{pH}$ (5.5 to 7.3), EC $\left(0.3\right.$ to $\left.0.8 \mathrm{dS} \cdot \mathrm{m}^{-1}\right)$, and nutrients in the pomace-amended media were intermediate but increased with the amount of pomace. Bulk density also increased with the amount of pomace (250 to $474 \mathrm{~g} \cdot$ liter $^{-1}$, air-dry weight basis), but aeration (31\% to $18 \%$ ) and moisture retention $(60 \%$ to $44 \%)$ decreased. Corresponding values were intermediate in the control: bulk density ( $\left.285 \mathrm{~g} \cdot \mathrm{liter}^{-1}\right)$, aeration $(28 \%)$, and moisture retention (49\%).

Despite these variations, all four species grew well and showed no significant difference in shoot dry weight (cedar 174-189; dogwood 116-139; euonymus 77-106 g/plant) or in leaf nutrient composition (data not shown) due to media, except for significantly higher shoot dry weight of Andorra juniper with $75 \%$ or $90 \%$ pomace (Table 1) and for moderately increasing leaf $\mathrm{Mn}$ content in Andorra juniper (37 to $56 \mathrm{mg} \cdot$ liter $^{-1}$ ) and Emerald cedar (44 to $57 \mathrm{mg} \cdot$ liter $^{-1}$ ) with increasing amounts of pomace.

During the 2 years of study, the $\mathrm{pH}$ tended to rise in the control medium or in those media with $25 \%$ to $50 \%$ pomace, remained steady with $75 \%$ pomace, and decreased with 90\% pomace. The final $\mathrm{pH}$ on 29 Aug. 1991 varied only between 6.9 and 7.0. Except on 6 July 1989, when the EC had increased to 1.2 and $1.5 \mathrm{dS} \cdot \mathrm{m}^{-1}$ in treatments with $25 \%$ and $50 \%$ pomace, respectively, EC in all treatments remained low $\left(0.1\right.$ to $\left.0.4 \mathrm{dS} \cdot \mathrm{m}^{-1}\right)$ thereafter, as in a previous study under similar experimental conditions (Chong et al., 1991).

Apple pomace apparently can be used as an organic amendment for container culture of ornamental nursery species. Notwithstanding the good growth of all species in all pomace-amended treatments, no more than $50 \%$ of the volume of the mix should be pomace because of significant shrinkage [>20\%) with $75 \%$ or more pomace (Table

\section{Literature Cited}

Chong, C., R.A. Cline, D.L. Rinker, and O.B. Allen. 1991. Growth and mineral nutrient status of containerized woody species in media amended with spent mushroom compost. J. Amer. Soc. Hort. Sci. 116:242-247.

Ontario Ministry of Agriculture and Food. 1990. Production recommendations for ornamentals and turf. Publ. 383, Queen's Printer for Ontario, Toronto.

Parks, N.J. 1979. Effect of soil amendments on crop yields. Agr. Can. Expt. Farm, Smithfield, Ont., Res. Rpt. p. 8.

Wang, H.J. and R.L. Thomas. 1989. Direct use of apple pomace in bakery products. J. Food Sci. 54(3):618-621.

van de Kamp, M. 1986. Apple pomace can be productive. Biocycle 27(3):39.

Table 1. Shoot dry weight of juniper and shrinkage of apple pomace-amended growing media at the

\begin{tabular}{|c|c|c|c|c|c|c|}
\hline Crop & $\begin{array}{l}45 \% \text { Bark } \\
45 \% \text { Peat } \\
10 \% \text { Sand } \\
\text { (control) }\end{array}$ & $\begin{array}{c}25 \% \text { Pomace } \\
65 \% \text { Peat } \\
10 \% \text { Sand } \\
\end{array}$ & $\begin{array}{c}50 \% \text { Pomace } \\
40 \% \text { Peat } \\
10 \% \text { Sand } \\
\end{array}$ & $\begin{array}{c}\text { 75\% Pomace } \\
15 \% \text { Peat } \\
10 \% \text { Sand }\end{array}$ & $\begin{array}{l}90 \% \text { Pomace } \\
10 \% \text { Sand }\end{array}$ & $\begin{array}{c}\text { LSD } \\
\alpha=0.05\end{array}$ \\
\hline \multicolumn{7}{|c|}{ Shoot dry wt (g/plant) } \\
\hline Juniper & 240 & 270 & 267 & 285 & 282 & 35 \\
\hline \multicolumn{7}{|c|}{ Shrinkage $(\mathrm{cm})^{\mathrm{y}}$} \\
\hline $\begin{array}{l}1989 \\
1990 \\
\end{array}$ & $\begin{array}{l}2.5 \\
3.1 \\
\end{array}$ & $\begin{array}{l}2.6 \\
3.2 \\
\end{array}$ & $\begin{array}{l}2.8 \\
3.8\end{array}$ & $\begin{array}{l}3.5 \\
4.3 \\
\end{array}$ & $\begin{array}{l}3.7 \\
4.5\end{array}$ & $\begin{array}{l}0.6 \\
0.5\end{array}$ \\
\hline
\end{tabular}

yDepth from container rim averaged over species. 